\title{
Errors in the measurement of serum electrolytes
}

\author{
G. S. THOMPSON AND E. SHERWOOD JONES ${ }^{1}$
}

From the Research Laboratories, Department of Medicine, University of Liverpool

SYNOPSIS When compared with results obtained by the authors in a department of medicine, the values obtained by three hospital laboratories for sodium, potassium, and chloride in normal and pathological sera were found to contain gross errors. In particular, the values obtained on sera from healthy subjects had a wide range when compared with the results obtained by the authors. The maximum acceptable analytical errors are suggested.

In day-to-day hospital practice reliance is placed on serum electrolyte estimations to recognize and treat body fluid disturbances. It seemed important to assess the errors in the determination of serum sodium, potassium, and chloride in hospital laboratories in our own area.

\section{METHOD}

The investigation lasted six months and was undertaken with the full cooperation of the consultant hospital staff. Samples of venous blood were taken from 31 healthy undergraduates and eight hospital in-patients thought to have electrolyte disturbances. The blood from each subject was submitted to laboratories of the Department of Medicine of Liverpool University and of three hospitals. In the case of the hospitals laboratories, all the blood samples were received through their wards, so that the investigation was 'blind'. In our own laboratory the analysts did not know the origin of the samples.

In the Department of Medicine, sodium and potassium were measured by internal standard fiame photometry (Baker, 1955; Amoore, Parsons, and Werkheiser, 1958). The diluted serum was 'bracketed' by standards which gave a linear calibration curve. Chloride was estimated iodometrically (Van Slyke and Hiller, 1947). To reduce volumetric error the serum dilutions were made with a micrometer syringe (Jones and Chambers, 1956). In the hospital laboratories, sodium and potassium were estimated on a direct-reading flame photometer (Evans Electroselenium, Ltd.) and chloride by the method of Schales and Schales (1941).

\section{RESULTS}

A statistical analysis of results on normal sera obtained by the Department of Medicine is shown in Table I. The standard deviations of the results in

'Present address: Clinica Pharmacology Unit, Whiston Hospital, Prescot, Lancashire.

Received for publication 16 March 1965.
TABLE I

SERUM ELECTROLYTE VALUES ON NORMAL SERA

\begin{tabular}{lccc} 
& $\begin{array}{c}\text { Sodium } \\
(m E q . / l .)\end{array}$ & $\begin{array}{l}\text { Potassium } \\
(\text { mEq./l. })\end{array}$ & $\begin{array}{c}\text { Chloride } \\
(m E q . / l .)\end{array}$ \\
\hline Number of observations & 31 & 30 & 23 \\
Mean value & 141.4 & $4 \cdot 16$ & $105 \cdot 1$ \\
Standard deviation & $2 \cdot 7$ & $0 \cdot 22$ & $2 \cdot 5$ \\
Student 't' & $2 \cdot 04$ & $2 \cdot 05$ & $2 \cdot 07$ \\
Confidence limits & $136-146.8$ & $3 \cdot 71-4 \cdot 61$ & $99 \cdot 9-110 \cdot 3$
\end{tabular}

TABLE II

STANDARD DEVIATIONS FOR ELECTROLYTE VALUES ON NORMAL SERA

\begin{tabular}{rlll} 
Hospital & $\begin{array}{l}\text { Sodium } \\
(m E q . / l .)\end{array}$ & $\begin{array}{l}\text { Potassium } \\
(m E q . / l .)\end{array}$ & $\begin{array}{l}\text { Chloride } \\
(m E q . / l .)\end{array}$ \\
\hline I & $8 \cdot 7$ & 0.40 & 6.8 \\
II & $4 \cdot 5$ & 0.39 & 4.2 \\
III & 5.8 & 0.42 & 4.1
\end{tabular}

the hospital laboratories for sodium, potassium, and chloride are given in Table II and it will be seen that these values are approximately twice those obtained by the authors. A comparison of the four laboratories can be made by reference to the scattergrams (Figs. 1-3). The solid circles are results from the normal subjects and the values on a small number of patients with clinical electrolyte disturbances are shown as crosses. The vertical lines represent the normal range quoted by each hospital laboratory. The electrolyte values obtained by the hospital laboratories on normal sera were widely distributed when compared with our own results. This is evident for all three variables but is especially marked for the sodium and chloride results from hospital I. The hospital results on normal sera were frequently outside the quoted normal ranges. This occurred for $48 \%$ of the sodium estimations from hospital I and for $55 \%$ of the chloride results from hospital III. 


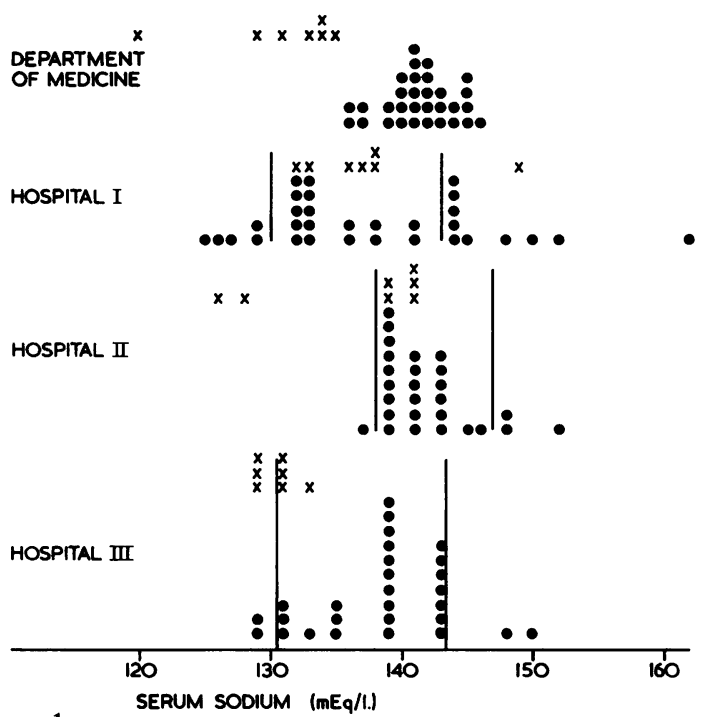

FIG. 1 .

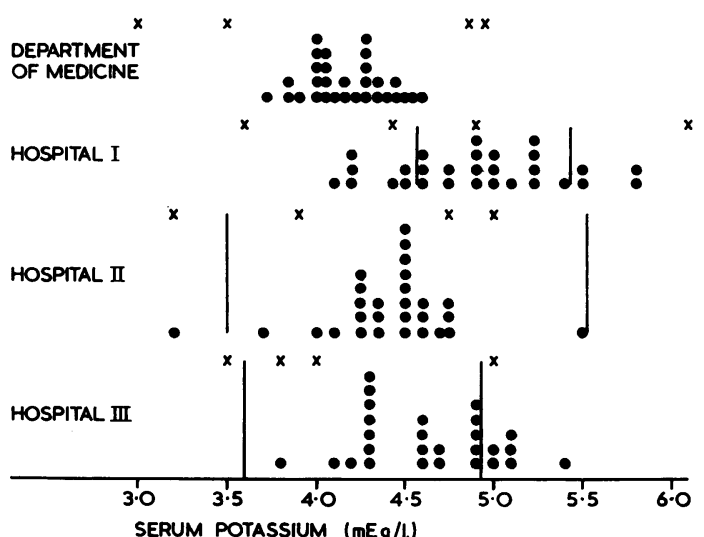

FIG. 2.

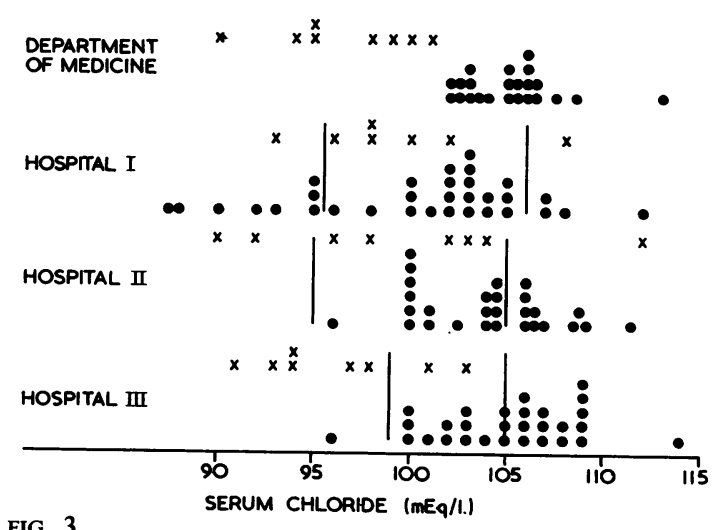

FIG 3. E. Sherwood Jones
For all three electrolytes, the hospital laboratories
obtained results on several pathological sera within the normal range. Furthermore, it should be noted $\vec{F}$ that there were large differences in the normalo ranges quoted by the three hospital laboratories. $\frac{1}{0}$ Results were not available on all the samples submitted.

It was also found that, for the same sample of blood, the serum sodium, potassium, and chloride ${ }^{\infty}$ values obtained by the hospital laboratories varied $\vec{O}$ widely. This fact is illustrated for serum sodium in Figure 4. The values obtained in the Department of ${ }_{\sigma}^{\omega}$

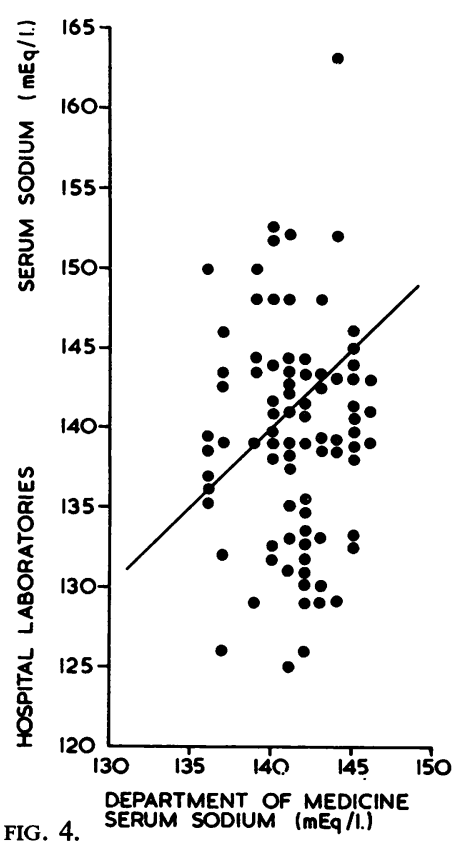

Medicine on normal sera were marked off on the $\frac{7}{0}$ abscissa. The results obtained by the hospital laboratories on the same samples are shown as $N$ solid circles. For example, the authors found that $N$ one sample contained $146 \mathrm{mEq}$. per litre and the $\mathrm{N}$ hospital results on this sample were 139,141 , and $143 \mathrm{mEq}$. per litre. In the Department of Medicine five samples of normal sera contained $141 \mathrm{mEq}$. of $\stackrel{\circ}{\complement}$ sodium per litre and the hospital results on these samples varied from 125 to $152 \mathrm{mEq}$. per litre, with one result 'missing'. If all the results were in agreement they would lie on a continuous line. In fact, a wide scatter occurred above and below the line. The $\frac{\rho}{\oplus}$ results in Fig. 4 were not corrected for the wide variations found by the hospital laboratories in the control sera. 


\section{DISCUSSION}

The results described above demonstrate the existence of errors in the measurement of serum electrolytes which are significant for clinical practice. Although comparable studies have been published in the United States, details of any British investigation have not been found. The international biochemical trial of 1954 was briefly reported by Wootton (1956) who commented: 'In the first place, this problem is universal and no country taking part maintains an adequate standard of laboratory precision'. Our results on normal sera are similar to those of Fawcett and Wynn (1956).

In the hospitals, laboratory errors were assessed by using commercial sera. The electrolyte estimations on these sera were performed only once a week and a quality control system (Wootton, 1964) was not used.

We are indebted to Lord Cohen of Birkenhead who suggested and organized the investigation and to Dr. D. V. Roberts for help during the preparation of this paper. G.S.T. was in receipt of a personal grant from the United Hospitals Research Committee.

\section{REFERENCES}

Amoore, J. E., Parsons, D. S., and Werkheiser, W. C. (1958). Biochem. J., 69, 236.

Baker, R. W. R. (1955). Ibid., 59, 566.

Fawcett, J. K., and Wynn, V. (1956). Brit. med. J., 2, 582.

Jones, E. S., and Chambers, A. (1956). J. med. Lab. Technol., 13, 562.

Schales, O., and Schales, S. S. (1941). J. biol. Chem., 140, 879.

Van Slyke, D. D., and Hiller, A. (1947). Ibid., 167, 107.

Wootton, I. D. P. (1956). Clin. Chem., 2, 296.

- (1964). Micro-analysis in Medical Biochemistry, 4th ed., p. 8. Churchill, London. 